\title{
The Demoiselle crane (Anthropoides virgo) population genetic structure in Russia
} \author{
V.Yu. Ilyashenko ${ }^{2}$, D.V. Politov ${ }^{1}$ \\ ${ }^{1}$ Vavilov Institute of General Genetics, RAS, Moscow, Russia \\ ${ }^{2}$ A.N. Severtsov Institute of Ecology and Evolution, RAS, Moscow, Russia \\ ${ }^{3}$ Daursky State Nature Biosphere Reserve, Nizhny Tsasuchey, Russia \\ ${ }^{4}$ Institute of Nature Resources, Ecology and Cryology, RAS, Chita, Russia \\ ${ }^{5}$ Oka Crane Breeding Center, Oka State Nature Biosphere Reserve, Brykin Bor, Russia \\ ${ }^{6}$ Ulyanovsk State Pedagogical University named after I.N. Ulyanov, Ulyanovsk, Russia \\ 7 Nature Reserve "Opukskiy", Feodosia, Russia \\ ${ }^{8}$ A.K. Tembotov Institute of Ecology of Mountain Territories, RAS, Nalchik, Russia \\ ${ }^{9}$ Dagestan State Nature Reserve, Makhachkala, Russia
}

E.A. Mudrik ${ }^{1}$ 团, E.I. Ilyashenko 2 , O.A. Goroshko ${ }^{3}, 4$, T.A. Kashentseva ${ }^{5}$, M.V. Korepov ${ }^{6}$, I.A. Sikorskiy ${ }^{7}$, G.S. Dzhamirzoev ${ }^{8,9}$

The Demoiselle crane (Anthropoides virgo Linneaus, 1758) is a widespread crane species of Eurasia distributed in the steppe and semi-desert zones from southeast Ukraine eastward to Northern China. The Demoiselle crane uses two wintering grounds in Africa and India corresponding to the European and Asian breeding parts of the range subdivided into several spatially separated breeding flocks. The first estimates of the genetic diversity and differentiation have been obtained from five of them: 1) Azov \& Black Sea, 2) Caspian, 3) Volga \& Ural, 4) South Siberian and 5) Eastern Asian sampled across the total breeding range in Russia using data from 10 microsatellite loci and the 1003-bp control region of mitochondrial DNA. In total, the Demoiselle crane demonstrates high level of observed $\left(H_{\mathrm{O}}=0.638 \pm 0.032\right)$ and expected $\left(H_{\mathrm{E}}=0.657 \pm 0.023\right)$ heterozygosity and haplotype diversity $(h=0.960)$. Genetic differentiation among populations has shown to be weak for both the microsatellite loci (Wright's $F_{\mathrm{ST}}=0.052$ or AMOVA estimate 0.016$)$ and $\mathrm{mtDNA}\left(F_{\mathrm{ST}}=0.040\right)$. No evidence of significant population structuring of the Demoiselle crane has been found using the STRUCTURE analysis of multilocus microsatellite genotypes and the NETWORK grouping of control region haplotypes. Despite the haplotype diversity was high, the nucleotide diversity of the species was low $(0.0033 \pm 0.0003)$. Negative but non-significant Tajima's and Fu's tests did not suggest the recent population expansion in the Demoiselle crane evolutionary history which contrasts to other cranes of the Palearctic (the Eurasian crane Grus grus, and the Hooded crane G. monacha). These data indicate more stable conditions for the Demoiselle crane breeding groups in the steppe zone in Pleistocene as compared to boreal and subarctic breeding grounds of other crane species.

Key words: Anthropoides virgo; microsatellite loci; Control Region; genetic variation; genetic differentiation; breeding groups.

\section{Популяционно-генетическая структура красавки Anthropoides virgo в России}

Е.А. МуАрик ${ }^{1} \otimes$, Е.И. ИАьяшенко 2 , О.А. Горошко ${ }^{3,4}$,

Т.А. Кашенцева ${ }^{5}$, М.В. Корепов ${ }^{6}$, И.А. Сикорский ${ }^{7}$,

Г.С. Ажамирзоев ${ }^{8,9}$, В.Ю. ИАьяшенко ${ }^{2}$, А.В. Политов ${ }^{1}$

${ }^{1}$ Институт общей генетики им. Н.И. Вавилова Российской академии наук, Москва, Россия

2 Институт проблем экологии и эволюции им. А.Н. Северцова Российской академии наук, Москва, Россия

${ }^{3}$ Государственный природный биосферный заповедник «Даурский», Нижний Цасучей, Россия

${ }^{4}$ Институт природных ресурсов, экологии и криологии Сибирского

отделения Российской академии наук, Чита, Россия

5 Питомник редких видов журавлей Окского государственного

биосферного заповедника, Брыкин Бор, Россия

${ }^{6}$ Ульяновский государственный педагогический университет

им. И.Н. Ульянова, Ульяновск, Россия

${ }^{7}$ Природный заповедник «Опукский», Феодосия, Россия

${ }^{8}$ Институт экологии горных территорий им. А.К. Темботова Российской академии наук, Нальчик, Россия

${ }^{9}$ Государственный природный заповедник «Дагестанский», Махачкала, Россия

Красавка (Anthropoides virgo Linnaeus, 1758) - широко распространенный вид журавлей Евразии, гнездящийся в степной и полупустынной зонах от Юго-Восточной Украины до Северного Китая. Красавка, гнездящаяся в европейской и азиатской частях ареала, зимует в Северо-Восточной Африке и Индии соответственно. Вследствие фрагментации мест обитания, гнездовая часть ареала вида подразделена на несколько географических группировок. С использованием данных 10 микросателлитных локусов и контрольного региона митохондриальной ДНК длиной 1003 пар оснований были получены первые результаты оценки генетического разнообразия и дифференциации пяти гнездовых группировок на территории России: 1) азово-черноморской; 2) прикаспийской; 3) волго-уральской; 4) южно-сибирской и 5) восточноазиатской. В целом красавка демонстрирует высокий уровень наблюдаемой $\left(H_{O}=0.638 \pm 0.032\right)$ и ожидаемой $\left(H_{\mathrm{E}}=0.657 \pm 0.023\right)$ гетерозиготности и гаплотипического разнообразия ( $h=0.960)$. Генетическая дифференциация гнездовых группировок оказалась низкой как по микросателлитным локусам ( $F_{S T}$ по Райту - 0.052, по данным AMOVA - 0.016), так и по митохондриальной ДНК $\left(F_{\mathrm{ST}}=0.040\right)$. Не обнаружено очевидной значимой популяционной структуры A. virgo ни по многолокусным микросателлитным генотипам при анализе STRUCTURE, ни по гаплотипам контрольного региона в NETWORK. Несмотря на высокое гаплотипическое разнообразие, нуклеотидное разнообразие $A$. virgo оказалось низким (0.0033 \pm 0.0003$)$. 
Отрицательные, но незначимые тесты Таджимы и Фу не подтвердили недавней популяционной экспансии красавки в ее эволюционной истории в отличие от других журавлей Палеарктики, например серого (Grus grus) и черного (G. monacha). Эти данные указывают на более стабильные условия для красавки в степной зоне в плейстоцене по сравнению с бореальными и субарктическими гнездовыми частями ареалов других видов журавлей.

Ключевые слова: Anthropoides virgo; микросателлитные локусы; контрольный регион; генетическая изменчивость; генетическая дифференциация; гнездовые группировки.

\section{HOW TO CITE THIS ARTICLE:}

Mudrik E.A., Ilyashenko E.I., Goroshko O.A., Kashentseva T.A., Korepov M.V., Sikorskiy I.A., Dzhamirzoev G.S., Ilyashenko V.Yu., Politov D.V. The Demoiselle crane (Anthropoides virgo) population genetic structure in Russia. Vavilovskii Zhurnal Genetiki i Selektsii = Vavilov Journal of Genetics and Breeding. 2018;22(5):586-592. DOI 10.18699/VJ18.398

T he Demoiselle crane (Anthropoides virgo Linneaus, 1758 ) is one of the most abundant and the least genetically studied crane species in the world. It is a widespread species breeding in the steppe and semi-desert zone of Eurasia from southeast Ukraine eastwards through the south of Russia, Kazakhstan, Kyrgyzstan, and Mongolia to Northern China (Meine, Archibald, 1996). The main breeding range can be conditionally divided into three parts: European, South Siberian/Central Asian and East Asian. Besides, two isolated populations recently have inhabited Eastern Turkey and North Africa. The habitats in the European Russia are most fragmented and can be subdivided into Azov \& Black Sea, Middle Don, Caspian and Volga \& Ural/Western Kazakhstan breeding groups (Belik et al., 2011). The Demoiselle crane is phenotypically and ethologically uniform throughout the range, and variation in nesting time in the north and south can be explained by the environmental conditions.

The total population number is estimated at 200,000 220,000 individuals (Ilyashenko, 2016a), and approximately $60,000-65,000$ of them inhabit Russia. Due to the total relatively high population size of the Demoiselle crane, its world conservation status as a species of the Least Concern tends to increase (www.iucnredlist.org). Red Data Book of the Russian Federation (2001) considers the Demoiselle crane as a recovering species. Despite the world high numbers, the Demoiselle crane experiences decline in several regions that led to its recognition as a locally threatened species tending to range contraction. During the 20th century it disappeared from most of territories westwards of the Black Sea as well as in Eastern Turkey and North Africa; its number continues to decline in Ukraine, Kyrgyzstan and Northern China as well as along the southern border of the range due to anthropogenic pressure, habitat degradation and long-term drought (Ilyashenko, 2016a, b).

The Demoiselle crane belongs to migratory species: birds from European and Asian parts of the breeding range use two wintering grounds in Africa and India, respectively. We are unaware of any data on genetic structure of the species in general or in particular localities including within-population levels of genetic diversity and spatial genetic differentiation. In this study, for the first time the genetic variation and differentiation of five Demoiselle crane breeding groups in Russia have been analyzed based on molecular data from nuclear microsatellite loci and mitochondrial DNA control region sequences. The objectives of our study were to compare parameters of popula- tion genetic structure of Demoiselle cranes from European and Asian parts differing by their breeding and wintering grounds and estimate the degree of genetic differentiation within and among them.

\section{Materials and methods}

Sample collection and DNA extraction. We studied 115 individuals from five breeding groups of the Demoiselle crane in Russia representing almost the whole breeding range of the species. The number of studied birds from each group was the following: Azov \& Black Sea (Republic of Crimea and Krasnodar Region) - 33 birds, Caspian (Republic of Kalmykia, Republic of Dagestan, Astrakhan Oblast, Stavropol Region, and the western part of Volgograd Oblast at the right Volga river bank) - 42, Volga \& Ural (Saratov Oblast, Samara Oblast and eastern part of Volgograd Oblast in Transvolga) - 4, South Siberia (Republic of Khakasia and two birds from the Omsk zoo supposedly caught in the steppe zone east of Altai Mountains) - 14, and Eastern Asia (Transbaikalia) - 22 (Supplemantary Figure) ${ }^{1}$. Some birds were captive but they originated from the known breeding location. The biological samples from the most studied cranes were obtained from the natural populations of $A$. virgo during our own field work mainly in the Caspian and Transbaikalian regions. The biomaterial was taken partly from chicks of wild pairs caught and then released in several region of European Russia according to permits from the Federal Service for Supervision of Natural Resources (Rosprirodnadzor) No. 104, 105 and 106 from 13.06.2017. The chicks were caught and released immediately after taking their feathers later on used for DNA extraction. For DNA isolation in the wild cranes, moulted and plucked feathers were used, while in the captive birds we used the blood taken during a planned clinical examination zoos. In the blood and plucked feathers DNA was extracted using the DIAtom ${ }^{\mathrm{TM}}$ DNAPrep100 Kit (Isogen Laboratories Ltd., Russia), and in the calamus and blood clot of moulted feathers - the using innuPREP Forensic Kit (Analytik Jena, Germany) according to the manufacturers' protocols.

Microsatellite genotyping. Individual genotyping was performed by 10 preliminary selected heterologous polymorphic loci isolated from the genomes of the Red-crowned crane Grus japonensis: Gj-M8, Gj-M15, Gj-M34 (Hasegawa et al., 2000), Gj-4066, Gj-8077 (Zou et al., 2010), the Blue crane Anthro-

\footnotetext{
1 Supplementary Figure is available in the online version of the paper: http://www.bionet.nsc.ru/vogis/download/pict-2018-22/appx10.pdf
} 
poides paradisea: Gpa12, Gpa38, Gpa39 (Meares et al., 2008) and the Whooping crane Grus americana: Gram22, Gram30 (Jones et al., 2010). Polymerase chain reactions (PCR) were conducted using GenPak PCR Core Kit (Isogen Laboratories Ltd., Russia). PCR products electrophoresis was performed in $6 \%$ polyacrylamide gel in Tris-EDTA-borate buffer system with subsequent gel staining with ethidium bromide and visualization in ultraviolet light using the Kodak Edas 290 gel documentation system (Kodak, USA). The size of observed alleles was defined by means of gel electrophoresis image analysis software GelAnalyzer (http://www.gelanalyzer.com).

Control Region sequencing. For the analysis of mitochondrial DNA (mtDNA) we amplified the Control Region with LC16575 (5'-ACAAAA GAAACC CCC AAA CTC A-3') and HC01342 (5'-AAG AAT TCT GCG GAT ACT TGC ATG T-3') primers following the PCR procedures recommended in (Hasegawa et al., 1999). PCR products were detected by electrophoresis with $1.5 \%$ agarose gel and then purified using Diatom DNA Clean-Up Kit (Isogen Laboratory, Russia). Subsequent sequencing was performed in both directions on ABI 3130 GeneticAnalyzer (Applied Biosystems, USA) at Evrogen (Moscow, Russia). Sequences have been deposited to GenBank under accession numbers MH286917-MH286933.

Data analysis. The parameters of genetic diversity, correspondence to Hardy-Weinberg equilibrium (HWE), F-statistics and analysis of molecular variance (AMOVA) by microsatellite loci were calculated using GenAlEx 6.5 (Peakall, Smouse, 2012). To reveal the population structure, Bayesian clustering analysis was implemented in STRUCTURE 2.3.4 (Pritchard et al., 2000; Porras-Hurtado et al., 2013) using an admixture model. The probability of genetic clusters number K was determined in Structure Harvester (Earl, vonHoldt, 2011). Subsequent analysis of the relevant $K$ value was done in CLUMPP v.1.1.2 (Jakobsson, Rosenberg, 2007). Visualization of the genetic structuring was realized in Distruct (Rosenberg, 2003). The alignment of the mitochondrial Control Region sequences was performed using MAFFT algorithm (Katoh et al., 2002) in Geneious 8.1.8 (Kearse et al., 2012). Alignment statistics and DNA polymorphism, Tajima's D (Tajima, 1989) and Fu's (Fu, 1997) tests were obtained from DnaSP v.5.10.01 (Librado, Rozas, 2009). Genetic subdivision $\left(F_{\mathrm{ST}}\right)$ for mtDNA data was calculated according to Hudson et al. (1992). A haplotype network diagram was constructed using the Medianjoining method in Network v4 (Bandelt et al., 1999).

\section{Results}

Microsatellite analysis. There were nine polymorphic microsatellite loci at Hardy-Weinberg equilibrium and only Gram 30 showed the lack of heterozygotes most likely due to the presence of null-alleles. From two to ten alleles and high levels of observed $\left(H_{\mathrm{O}}=0.531-0.843\right)$ and expected $\left(H_{\mathrm{E}}=0.533-0.809\right)$ heterozygosity have been fixed in the Demoiselle crane by all studied loci (Table 1).

Generally, Demoiselle crane breeding groups demonstrate high level of genetic polymorphism by microsatellite loci: 5.2 alleles per locus $\left(N_{\mathrm{A}}\right), H_{\mathrm{O}}=0.638 \pm 0.032, H_{\mathrm{E}}=0.657 \pm$ 0.023 and low inbreeding coefficient $\left(F_{\text {IS }}=-0.023\right)$ insignificantly differed from zero. They are also characterized by weak genetic differentiation level by $\operatorname{AMOVA}\left(F_{\mathrm{ST}}=0.016\right)$ and Wright's $\left(F_{\mathrm{ST}}=0.052\right) F$-statistics (Table 2). Samples with low number of individuals (Volga \& Ural and South Siberia) showed significant deviations in $H_{\mathrm{O}}$ and $H_{\mathrm{E}}$ levels that led to significant heterozygosity excess $\left(F_{\text {IS }}=-0.339\right)$ in the Volga $\&$ Ural location and deficiency of heterozygotes $\left(F_{\text {IS }}=0.209\right)$ in the South Siberia sample. In all other samples, genotype distributions corresponded to Hardy-Weinberg equilibrium. Unbiased estimates of the expected heterozygosity were lower in European populations $\left(\mathrm{u} H_{\mathrm{E}}=0.634 \pm 0.035\right)$ as compared to Asian locations $\left(\mathrm{u} H_{\mathrm{E}}=0.691 \pm 0.020\right)$.

The European breeding groups of the Demoiselle crane were more genetically differentiated (AMOVA $F_{\mathrm{ST}}=0.021$, Wright's $F_{\mathrm{ST}}=0.064$ ) than the Asian locations (AMOVA $F_{\mathrm{ST}}=0.009$, Wright's $F_{\mathrm{ST}}=0.012$ ). The AMOVA analysis demonstrated that $94 \%$ of Demoiselle crane genetic variation

Table 1. Characterization of 10 microsatellite loci in the Demoiselle crane

\begin{tabular}{|c|c|c|c|c|c|c|}
\hline Locus & Repeat motif & $A$ & Observed alleles, bp & $H_{0}$ & $H_{\mathrm{E}}$ & HWE deviation \\
\hline$G j-M 8^{£}$ & $(\mathrm{TC})_{10}$ & 2 & 106,112 & 0.598 & 0.617 & ns \\
\hline$G j-M 15^{f}$ & $(\mathrm{GT})_{11}$ & 2 & 112,116 & 0.643 & 0.633 & ns \\
\hline$G j-M 34^{£}$ & $(\mathrm{CA})_{7}$ & 4 & $126,130,132,134$ & 0.606 & 0.608 & ns \\
\hline $\mathrm{Gpa}^{+} 2^{+}$ & $(\text {GATA })_{11}$ & 7 & $230,234,238,242,246,250,254$ & 0.678 & 0.711 & ns \\
\hline$G p a 38^{\dagger}$ & $(\mathrm{CTAT})_{13}$ & 6 & 186, 190, 194, 198, 202, 206 & 0.713 & 0.747 & ns \\
\hline $\mathrm{Gpa3}^{\dagger}$ & $\begin{array}{l}(\mathrm{GA})_{2} \\
(\mathrm{GATA})_{13}\end{array}$ & 10 & $104,112,116,120,124,128,132,136,140,144$ & 0.843 & 0.809 & ns \\
\hline Gram $22^{\S}$ & $(A A A C)_{9}$ & 8 & $152,156,160,164,168,172,176,180$ & 0.574 & 0.537 & ns \\
\hline Gram $30^{\S}$ & $(\mathrm{AAGG})_{7}$ & 10 & $154,158,166,170,174,178,182,186,190,194$ & 0.617 & 0.726 & ${ }^{*}(0.027)$ \\
\hline Gj4066 & $(\text { ATAG })_{9}$ & 4 & $133,137,141,149$ & 0.531 & 0.533 & ns \\
\hline Gj8077 & $(\mathrm{CTG})_{13}$ & 3 & $172,175,178$ & 0.603 & 0.606 & ns \\
\hline
\end{tabular}

Note: $A$ - number of alleles; bp - base pairs; $H_{\mathrm{O}}$ - observed heterozygosity; $H_{E}$ - expected heterozygosity; HWE deviation - deviation from Hardy-Weinberg equilibrium: ns - nonsignificant, ${ }^{*}$ significant at the $0.05 \%$ probability level. Loci taken from: ${ }^{£}$ (Hasegawa et al., 2000$) ;{ }^{\dagger}$ (Meares et al., 2008 ); ${ }^{\S}$ (Jones et al., 2010$)$; $¥$ (Zou et al., 2010). 
Table 2. Parameters of population genetic structure for five breeding populations of the Demoiselle crane in Russia estimated by 10 microsatellite loci

\begin{tabular}{|c|c|c|c|c|c|c|c|}
\hline Breeding groups & $N$ & $N_{A}$ & $\mathrm{H}_{\mathrm{O}}$ & $H_{\mathrm{E}}$ & $\mathrm{u} H_{\mathrm{E}}$ & $F_{1 S}$ & $F_{\mathrm{ST}}$ (Wright's/AMOVA) \\
\hline Azov \& Black Sea & 33 & 5.3 & $0.598 \pm 0.046$ & $0.628 \pm 0.050$ & $0.637 \pm 0.051$ & 0.035 & \\
\hline Caspian & 42 & 6.3 & $0.643 \pm 0.057$ & $0.628 \pm 0.044$ & $0.636 \pm 0.044$ & -0.025 & \\
\hline Volga \& Ural & 4 & 3.5 & $0.750 \pm 0.116$ & $0.551 \pm 0.077$ & $0.629 \pm 0.088$ & -0.339 & \\
\hline Average by the European group & 79 & 5.1 & $0.664 \pm 0.051$ & $0.602 \pm 0.033$ & $0.634 \pm 0.035$ & -0.110 & $0.064 / 0.021$ \\
\hline South Siberian & 14 & 5.2 & $0.527 \pm 0.070$ & $0.665 \pm 0.032$ & $0.690 \pm 0.033$ & 0.209 & \\
\hline Eastern Asian & 22 & 5.3 & $0.670 \pm 0.027$ & $0.677 \pm 0.026$ & $0.693 \pm 0.027$ & 0.004 & \\
\hline Average by the Asian group & 36 & 5.3 & $0.599 \pm 0.046$ & $0.671 \pm 0.020$ & $0.691 \pm 0.020$ & 0.106 & $0.012 / 0.009$ \\
\hline Total for five breeding groups & 115 & 5.2 & $0.638 \pm 0.032$ & $0.630 \pm 0.022$ & $0.657 \pm 0.023$ & -0.023 & $0.052 / 0.016$ \\
\hline
\end{tabular}

Note: $N$ - sample size; $N_{A}$ - allele number per locus; $H_{O}$ - observed heterozygosity; $H_{E}$ - expected heterozygosity; uHE - unbiased expected heterozygosity; $F_{\mathrm{IS}}$ - intrapopulation coefficient of inbreeding; $F_{\mathrm{ST}}$ - among population coefficient of inbreeding.

was concentrated within individuals, $5 \%$ - among individuals, and $1 \%$-among populations. No evident population structure among different geographical breeding populations of this species has been revealed by Bayesian clustering analysis in STRUCTURE based on microsatellite loci with most likely estimated cluster number $\mathrm{K}=4$ (Fig. 1). However, some increase in proportion of 'green', 'red' and 'yellow' clusters in eastern samples can be considered as a trend to starting process of differentiation among Demoiselle cranes wintering in Africa and India.

MtDNA analysis. The Control Region sequences of the Demoiselle Crane with full-length 1003 bp were obtained for 23 birds from different populations. This fragment contained 20 variable sites including ten singleton sites, nine parsimonyinformative sites and one inserted site. Among the 23 studied individuals, a total of 17 haplotypes were defined: 12 and 5 in European and Asian parts of the breeding range, respectively. Among European birds, eight haplotypes (H2, H3, H5, H6, H7, H9, H10, H11) were unique to the Caspian breeding group, one haplotype (H12) was unique to Volga \& Ural location, and three haplotypes were shared by Azov \& Black Sea and Volga \& Ural (H1) and Caspian and Volga \& Ural (H4, H8) breeding groups (Table 3, see Suppl. Figure). All five Asian haplotypes were unique: one to the South Siberian (H13) and four to the Eastern Asian (H14, H15, H16, H17) parts of the breeding range so as European and Asian breeding groups did not share any mitotypes.

In general, the haplotype diversity $(h)$ of the mitochondrial Control Region in the Demoiselle crane was exclusively high ( $h=0.960 \pm 0.026)$. The overall nucleotide diversity was low $(\pi=0.0033 \pm 0.0003)$. The small number of analyzed haplotypes did not allow us to compare all breeding populations but the genetic differentiation between European and Asian parts of the breeding range by mtDNA sequences also was low $\left(F_{\mathrm{ST}}=0.040\right)$ corresponding to the microsatellite data. The test for deviation from selective neutrality of Tajima $(D=-1.255)$ and $\mathrm{Fu}\left(F_{\mathrm{S}}=-9.712\right)$ were negative but non-significant and did not show the evidence of population expansion of $A$. virgo. Lack of typical star-like structure of haplotype network also suggests no recent bottlenecks and subsequent expansion (Avise, 2000). Despite five identified Asian haplotypes were

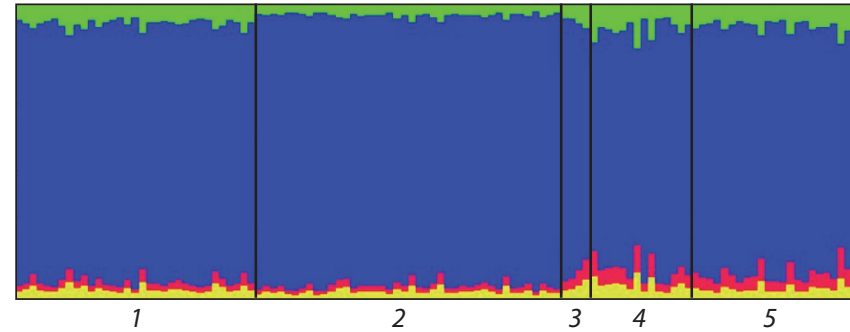

Fig. 1. Model-based clustering results for multi-loci individual genotypes of the Demoiselle crane iteratively assigned to four genetic groupings $(\mathrm{K}=4)$.

1 - Azov \& Black Sea, 2 - Caspian, 3 - Volga \& Ural, 4 - South Siberian, 5 - Eastern Asian breeding groups.

unique, they are incorporated in general network and do not form a separate haplogroup. Median haplotype network did not reveal highly diverged haplogroups that can be attributed for European and Asian lineages (Fig. 2, see Suppl. Figure).

\section{Discussion}

The Demoiselle crane demonstrates a high level of genetic diversity by nuclear microsatellite loci $\left(H_{\mathrm{O}}=0.638 \pm 0.032\right.$, $\left.H_{\mathrm{E}}=0.657 \pm 0.023\right)$ and Control Region of mtDNA $(h=0.960)$. We did not find a significant genetic subdivision of the species across its breeding range from the Azov \& Black Sea coast to the Transbaikalia $\left(F_{\mathrm{ST}}=0.016\right.$ and 0.040 by microsatellite loci and mtDNA, respectively). In general, the weak genetic differentiation in bird populations is common for the migratory and especially widespread species. The Gruidae family includes the migratory and non-migratory species as well as species consisting of migratory and non-migratory subspecies or populations. Significant level of genetic differentiation due to the gene flow limitation has been revealed among the subspecies of the non-migratory Sarus crane Grus antigone by microsatellite loci $\left(F_{\mathrm{ST}}=0.210\right)$ (Jones et al., 2005) and isolated populations of the non-migratory Wattled crane Bugeranus carunculatus both by microsatellite loci $\left(F_{\mathrm{ST}}=0.100\right)$ and control region of mtDNA $\left(F_{\mathrm{ST}}=0.450\right)$ (Jones et al., 2006). In migratory crane species, the genetic differentia- 
Table 3. Distribution of 17 haplotypes of the control region among five breeding groups of the Demoiselle crane

\begin{tabular}{|c|c|c|c|c|c|c|c|}
\hline \multirow[t]{2}{*}{ Haplotype } & \multirow{2}{*}{$\begin{array}{l}\text { GenBank } \\
\text { accession number }\end{array}$} & \multicolumn{5}{|l|}{ Breeding group } & \multirow[t]{2}{*}{ Total } \\
\hline & & Azov \& Black Sea & Caspian & Volga \& Ural & South Siberian & Eastern Asian & \\
\hline $\mathrm{H} 1$ & MH286917 & 1 & & 1 & & & 2 \\
\hline $\mathrm{H} 2$ & MH286918 & & 3 & & & & 3 \\
\hline H3 & MH286919 & & 2 & & & & 2 \\
\hline $\mathrm{H} 4$ & $\mathrm{MH} 286920$ & & 1 & 1 & & & 2 \\
\hline H5 & MH286921 & & 1 & & & & 1 \\
\hline H6 & MH286922 & & 1 & & & & 1 \\
\hline $\mathrm{H} 7$ & MH286923 & & 1 & & & & 1 \\
\hline H8 & MH286924 & & 1 & 1 & & & 2 \\
\hline H9 & MH286925 & & 1 & & & & 1 \\
\hline $\mathrm{H} 10$ & MH286926 & & 1 & & & & 1 \\
\hline $\mathrm{H} 11$ & MH286927 & & 1 & & & & 1 \\
\hline $\mathrm{H} 12$ & MH286928 & & & 1 & & & 1 \\
\hline $\mathrm{H} 13$ & MH286929 & & & & 1 & & 1 \\
\hline H14 & MH286930 & & & & & 1 & 1 \\
\hline H15 & MH286931 & & & & & 1 & 1 \\
\hline H16 & MH286932 & & & & & 1 & 1 \\
\hline H17 & MH286933 & & & & & 1 & 1 \\
\hline Total & & 1 & 13 & 4 & 1 & 4 & 23 \\
\hline
\end{tabular}

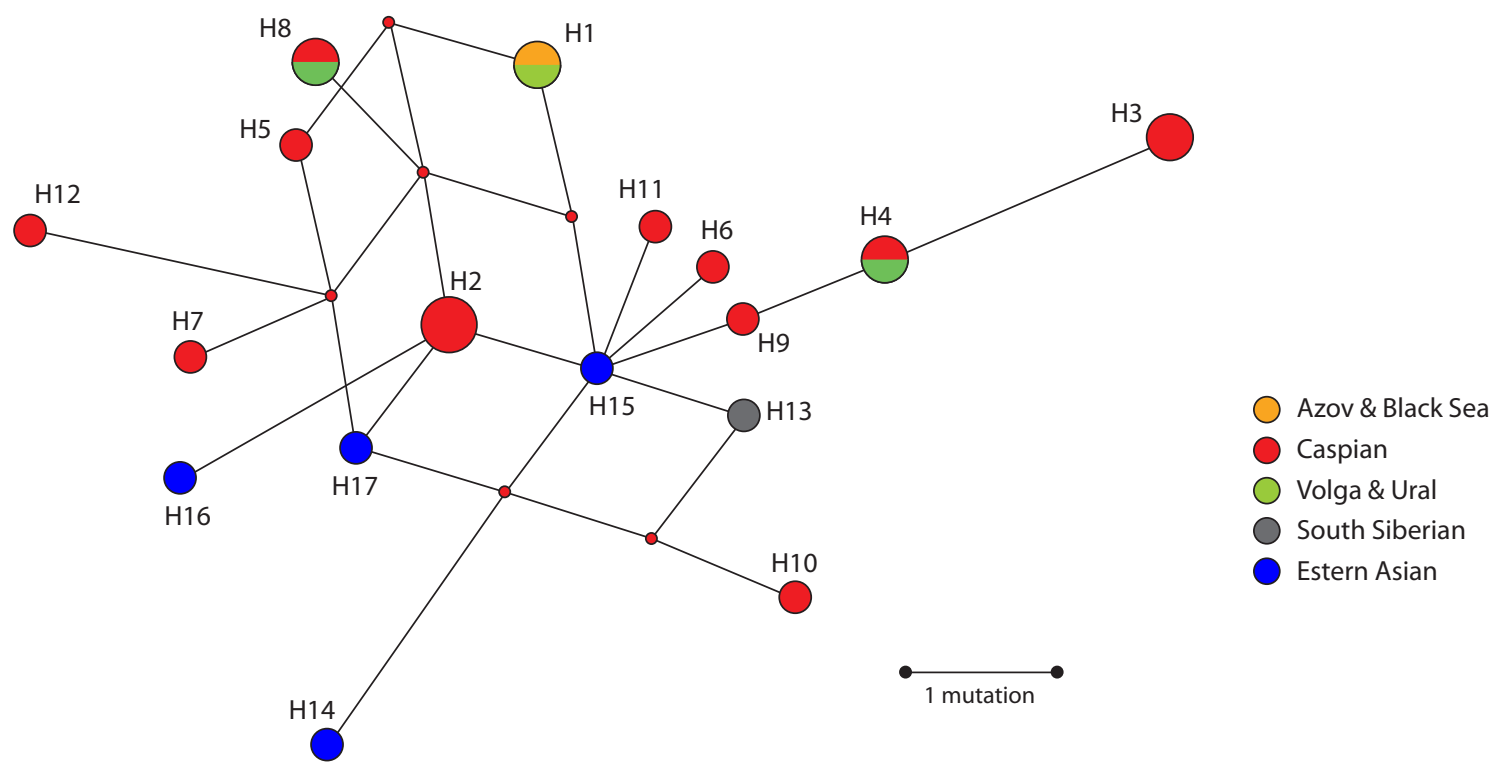

Fig. 2. Median-joining network of the Demoiselle crane haplotypes named as in Table 3.

The circle size is proportional to the number of individuals; the black spots represent interior nodes; connector length is proportional to the number of mutations between haplotypes.

tion of populations including isolated ones was usually low by different molecular markers not only in the wide-spread Eurasian crane G. grus (Haase, Ilyashenko, 2012; Mudrik et al., 2015) but also in the rare species like the Red-crowned crane $G$. japonensis having the migratory and non-migratory populations (Hasegawa et al., 1999, 2000; Sugimoto et al.,
2015), the Siberian crane G. leucogeranus having two isolated populations (Ponomarev et al., 2004), and the Hooded crane G. monacha (Zhang et al., 2012). As for the Sandhill crane $G$. canadensis, the species divided to six subspecies, shows strong genetic differentiation $\left(F_{\mathrm{ST}}=0.480\right)$ between two mitochondrial lineages: the first one was composed of only one 
migratory arctic subspecies, and the second one combined both the remaining non-migratory and migratory subspecies differentiation among which was low $F_{\mathrm{ST}}=0.066$ (Rhymer et al., 2001).

We can conclude that for the Demoiselle crane Pleistocene glaciation did not cause a significant disruption of the initial common range located in the steppe zone, and they were relatively slightly affected by ice age events. Thus, fragmentation of the species range could be likely attributed to in late Holocene/Anthropocene. The Demoiselle crane did not experience substantial demographic changes like bottlenecks and expansions, retaining a typical for migratory birds level of genetic diversity and differentiation. Despite the idea of complete isolation of western breeding groups wintering in Africa from Asian breeding groups migrating for winter to India, gene flow between them may have ceased recently and/ or incompletely. In other words, ever continuous range of the Demoiselle crane disrupted so late in its evolutionary history that differences has not accumulated yet as it has happened in some other species cited above. Nevertheless, the already started process of differentiation between European and Asian breeding groups of the Demoiselle crane is becoming evident from the presented multilocus analysis of genotypic variation, and the main cause of such subdivision is using different migration flyways and wintering sites by birds of these groupings. Another reason for the observed level of differentiation could be low sensitivity of the selected genetic markers (microsatellite loci and control region) so that efforts should be made to develop and use additional marker types such as nuclear gene sequences and SNPs.

\section{Acknowledgments}

The study was supported by the project of Russian Foundation of Basic Research No. 17-04-01287, programs of Presidium RAS No. 41 "Biological diversity and biological resources of Russia" (state assignment 0112-2018-0025) and No. 32 "Evolution of organic world. Role and influence of planetary processes" (state assignment 0112-2018-0027), program of Eurasian Regional Association of Zoos and Aquariums "Conservation of cranes of Eurasia" and Budget state assignment 0112-2016-0002.

We thank K.M. Kuniev, V.G. Kalmykov, G.A. Kalmykova, G.N. Moskov, V.M. Muzaev, Yu.N. Arylov, E.V. Gugueva, T.V. Selezneva, I.P. Ariulina, A.S. Urusova, A.G. Grinko for their invaluable assistance during our fieldwork. The birds were handled in accordance with the approved national guidelines for the care and use of laboratory animals. All the experiments were approved by Ethics Committee on Animal Care and Use of Vavilov Institute of General Genetics of RAS (approval No. 1 of 15.05.2017).

\section{Conflict of interest}

The authors declare they have no conflict of interest.

\section{References}

Avise J.C. Phylogeography: The history and formation of species. Cambridge: Harvard Univ. Press, 2000.

Bandelt H.-J., Forster P., Röhl A. Median-joining networks for inferring intraspecific phylogenies. Mol. Biol. Evol. 1999;16:37-48. DOI 10.1093/oxfordjournals.molbev.a026036.
Belik V.P., Guguyeva E.V., Vetrov V.V., Milobog Y.V. The Demoiselle crane in the northwestern Caspian lowland: distribution, number, and breeding success. Cranes of Eurasia (Biology, Distribution, Migrations, Management). 2011;4:157-174.

Earl D.A., vonHoldt B.M. STRUCTURE HARVESTER: a website and program for visualizing STRUCTURE output and implementing the Evanno method. Conserv. Genet. Res. 2011;4(2):359-361. DOI 10.1007/s12686-011-9548-7.

Fu Y.X. Statistical tests of neutrality of mutations against population growth, hitchhiking and background selection. Genetics. 1997;147: 915-925.

Haase M., Ilyashenko V. A glimpse on mitochondrial differentiation among four currently recognized subspecies of the common crane Grus grus. Ardeola. 2012;59(1):131-136.

Hasegawa O., Ishibashi Y., Abe S. Isolation and characterization of microsatellite loci in the red-crowned crane Grus japonensis. Mol. Ecol. 2000;9:1677-1678.

Hasegawa O., Takada S., Yoshida M.C., Abe S. Variation of mitochondrial control region sequences in three crane species, the redcrowned crane Grus japonensis, the common crane G. grus and the hooded crane G. monacha. Zool. Sci. 1999;16:685-692.

Hudson R.R., Slatkin M., Maddison W.P. Estimation of levels of gene flow from DNA sequence data. Genetics. 1992;132(2):583-589.

Ilyashenko E.I. Changes in Demoiselle crane status over the last 20 years. Proc. of the VIIIth Europ. Crane Conf. Gallocanta, Spain, 10-14 Nov. 2014. Association Amigos de Gallocanta, 2016a;80-88.

Ilyashenko E.I. Estimated numbers of cranes (Gruiformes, Gruidae) in Northern Eurasia at the beginning of the twenty-first century. Biol. Bull. 2016b;43(9):1048-1051. DOI 10.1134/S1062359016090119.

Jakobsson M., Rosenberg N.A. CLUMPP: a cluster matching and permutation program for dealing with label switching and multimodality in analysis of population structure. Bioinformatics. 2007;2(14): 1801-1806. DOI 10.1093/bioinformatics/btm233.

Jones K.L., Barzen J., Ashley M.V. Geographic partitioning of microsatellite variation in the sarus crane. Anim. Conserv. 2005;8:1-8 DOI 10.1017/S1367943004001842.

Jones K.L., Henkel J.R., Howard J.J., Lance S.L., Hagen C., Glenn T.C. Isolation and characterization of 14 polymorphic microsatellite DNA loci for the endangered Whooping crane (Grus americana) and their applicability to other crane species. Conserv. Gen. Res. 2010;2(1): 251-254. DOI 10.1007/s12686-010-9196-3.

Jones K.L., Rodwell L., McCann K.I., Verdoorn J.H., Ashley M.V. Genetic conservation of South African wattled cranes. Biol. Conserv. 2006;127:98-106. DOI 10.1016/j.biocon.2005.07.016.

Katoh K., Misawa K., Kuma K., Miyata T. MAFFT: a novel method for rapid multiple sequence alignment based on fast Fourier transform. Nucleic Acids Res. 2002;30(14):3059-3066. DOI 10.1093/nar/gkf436.

Kearse M., Moir R., Wilson A., Stones-Havas S., Cheung M., Sturrock S., Buxton S., Cooper A., Markowitz S., Duran C., Thierer T., Ashton B., Mentjies P., Drummond A. Geneious Basic: an integrated and extendable desktop software platform for the organization and analysis of sequence data. Bioinformatics. 2012;28(12):1647-1649. DOI 10.1093/bioinformatics/bts199.

Librado P., Rozas J. DnaSP v5: a software for comprehensive analysis of DNA polymorphism data. Bioinformatics. 2009;25(11):14511452. DOI 10.1093/bioinformatics/btp187.

Meares K., Dawson D., Horsburgh G.J., Perri M.R., Burke T., Taylor T.D. Characterisation of 14 blue crane Grus paradisea (Gruidae, AVES) microsatellite loci for use in detecting illegal trade. Conserv. Genet. 2008;9:1363-1367. DOI 10.1007/s10592-007-9490-0.

Meine C.D., Archibald G.W. (Eds.) The Cranes: Status Survey and Conservation Action Plan. IUCN, Gland, Switzerland, and Cambridge, U.K., 1996.

Mudrik E.A., Kashentseva T.A., Redchuk P.S., Politov D.V. Microsatellite variability data confirm low genetic differentiation of Western and Eastern subspecies of Common crane Grus grus L. (Gruidae, Aves). Mol. Biol. 2015;49(2):260-266. DOI 10.1134/ S0026893315020090. 
Peakall R., Smouse P.E. GenAlEx 6.5: genetic analysis in Excel. Population genetic software for teaching and research - an update. Bioinformatics.2012;28(19):2537-2539.DOI10.1093/bioinformatics/bts460.

Ponomarev A., Tatarinova T., Bubyakina V., Smagulova F., Kashentseva T., Morozov I. Variation of mitochondrial DNA D-loop sequences in the endangered Siberian crane Grus leucogeranus Pallas. Conserv. Genet. 2004;5:847-851.

Porras-Hurtado L., Ruiz Y., Santos C., Phillips C., Carracedo Á., Lareu M.V. An overview of STRUCTURE: applications, parameter settings, and supporting software. Front. Genet. 2013;4:98. DOI 10.3389/fgene.2013.00098

Pritchard J.K., Matthew S., Peter D. Inference of population structure using multilocus genotype data: linked loci and correlated allele frequencies. Genetics. 2000;164(4):1567-1587. DOI 10.3410/ f.1015548.197423.

Red Data Book of the Russian Federation. Animals. Moscow: Astrel, 2001.

Rhymer J.M., Fain M.G., Austin J.E., Johnson D.H., Krajewski C. Mitochondrial phylogeography, subspecific taxonomy, and conserva- tion genetics of sandhill cranes (Grus canadensis; Aves: Gruidae). Conserv. Gen. 2001;2:203-218.

Rosenberg N.A. Distruct: a program for the graphical display of population structure. Mol. Ecol. Notes. 2003;4(1):137-138. DOI 10.1046/ j.1471-8286.2003.00566.x.

Sugimoto T., Hasegawa O., Azuma N., Masatomi H., Sato F., Matsumoto F., Masatomi Y., Izumi H., Abe S. Genetic structure of the endangered red-crowned cranes in Hokkaido, Japan and conservation implications. Conserv. Genet. 2015;16:1395-1401. DOI 10.1007/ s10592-015-0748-7.

Tajima F. Statistical method for testing the neutral mutation hypothesis by DNA polymorphism. Genetics. 1989;123:585-595.

Zhang L., Zhou L., Dai Y. Genetic structure of wintering Hooded Cranes (Grus monacha) based on mitochondrial DNA D-loop sequences. Chinese Birds. 2012;3(2):71-81. DOI 10.5122/cbirds.2012.0012.

Zou H.F., Dong H.Y., Kong W.Y., Ma J., Liu J. Characterization of 18 polymorphic microsatellite loci in the red-crowned crane (Grus japonensis), an endangered bird. Anim. Sci. J. 2010;81(4):519-522. DOI 10.1111/j.1740-0929.2010.00779.x. 